\title{
Studies on the Hydrophysiological Rhythms of Citrus Trees
}

\author{
III. Effect of Soil Temperature on the Cyclic \\ Fluctuations of Leaf Thickness \\ Kazuomi KADOYA \\ College of Agriculture, Ehime University, Matsuyama
}

\begin{abstract}
Summary
To examine the effect of soil temperature on cyclic fluctuations, experiments were carried out under prescribed environmental conditions.

Fluctuations in leaf thickness were monitored by a differential transformer and the temperature of the same leaf by a thermocouple. The cyclic fluctuations in leaf thickness followed those of the leaf temperature. Harmonic analysis indicated that the time lag was about $553 \mathrm{sec}$ to $641 \mathrm{sec}$.

When the soil temperature at the center of the pot was lowered, the absolute leaf thickness decreased in accompanying cycling. However, the cyclic fluctuations disappeared when the soil temperature was further lowered. The critical temperature was $17^{\circ} \mathrm{C}$ in early October and $11^{\circ} \mathrm{C}$ in late November. In early October, the cyclic fluctuations appeared again in two and a half hours when the soil temperature was raised and did not disappear even when the soil temperature reached to $36^{\circ} \mathrm{C}$. In late November, however, it took more time to recover the cyclic fluctuations and above $35^{\circ} \mathrm{C}$ they became irregular again. From these results it was postulated that root adaptability to temperature in terms of cyclic phenomenon changed with the advancement of the season. Further study is reqired to clarify how root activity plays a role in stomatal movements.
\end{abstract}

\section{Introduction}

In the previous paper (7), the author pointed out that cyclic fluctuations in leaf thickness appeared during the growing seasons in the year, while they disappeared in winter even though the air temperature during the investigation was controlled within a range of 25 to $30^{\circ} \mathrm{C}$. The result shows an intimate relationship between the phenomena and the activities of plant parts, especially that of the root.

Hino et al. (5) reported that the rate of photosynthesis of satsuma mandarin trees in the field was so low that net photosynthesis could hardly be observed even on a fine day, when the soil temperature of the root zone was lowered to about $0^{\circ} \mathrm{C}$. Their experimental results show that root activity might affect the stomatal movements.

This paper reports the effect of soil temper-

Received for publication July 26, 1977 ature in the root zone upon cyclic fluctuations in leaf thickness.

\section{Meterials and Methods}

The experiment was carried out as mentioned previously in a prescribed environment $(6,7)$. A differential transformer (Shinko Denshi Co. Ltd. Model ICP-05) was set vertically on a leaf of a one-year-old potted Natsudaidai seedling (Citrus natsudaidai Hayata). Potted seedlings were grown and kept in the field until just before the experiment.

A Toshiba lamp, Type D 400, was used for the irradiation. The light intensity was 30 $\mathrm{klx}$ at the leaf surface. The air temperature was adjusted within a range of 20 to $23^{\circ} \mathrm{C}$. Temperature controlled water was circulated around a double layered box into which the pot of the seedling was fixed. Thus, it was possible to adjust the temperature at the center of the pot as planned. The soil temperature of the pot and the air temperature 


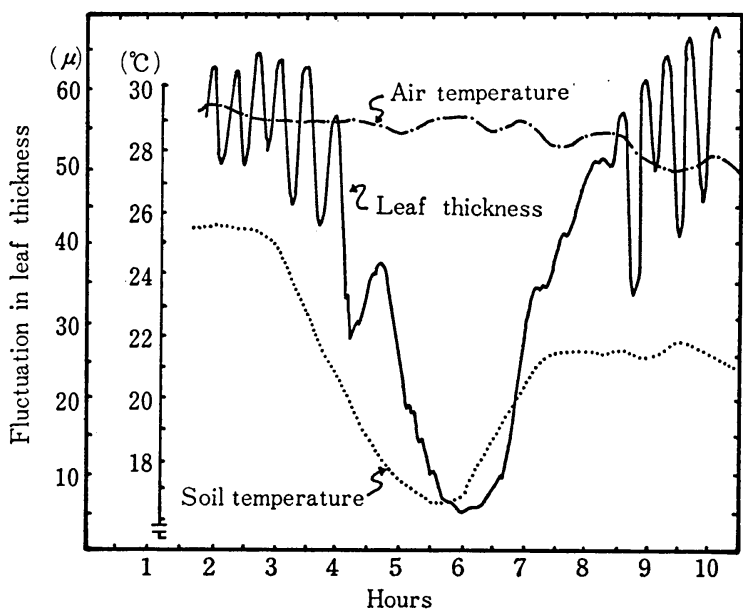

Fig. 1. Effect of low temperature on the cyclic fluctuations of leaf thickness in early October.

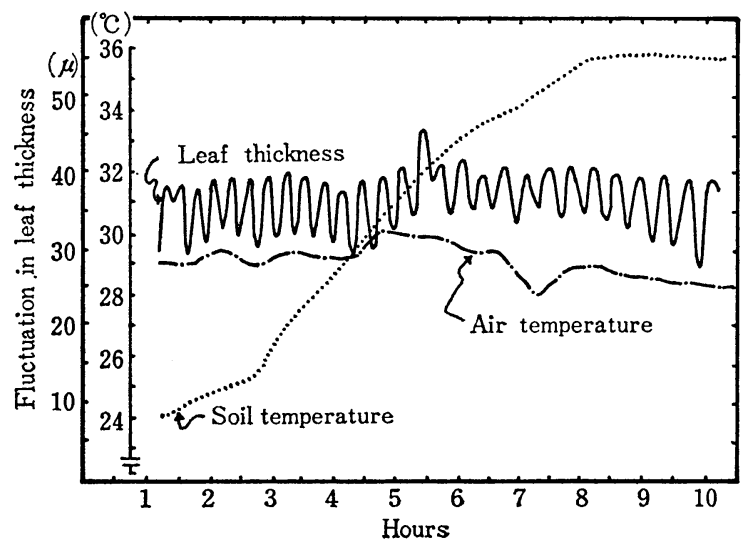

Fig. 2. Effect of high soil temperature on the cyclic fluctuations of leaf thickness in the middle of October.

were recorded continuously by the thermister thermometers. For leaf temperature monitoring, a copper and constantan wire, $0.1 \mathrm{~mm}$ in diameter, was attached on the lower side of the leaf. At the same time cyclic fluctuations in leaf thickness were observed on the same leaf.

\section{Results}

Fig. 1 shows the effect of soil temperature on the cyclic fluctuations in leaf thickness in early October. With a decrease of soil temperature from 25.5 to $16.5^{\circ} \mathrm{C}$, the leaf thickness was also decreased. Although cyclic fluctuations could be observed at the beginning of the treatment, the fluctuations became irregular below $20^{\circ} \mathrm{C}$ and finally disappeared at $17^{\circ} \mathrm{C}$. After the soil temperature was lowered to $16.5^{\circ} \mathrm{C}$, it was raised again at a rate of $2.5^{\circ} \mathrm{C}$ per hour to $21.5^{\circ} \mathrm{C}$. The leaf thickness responded to the changes of the soil temperature by increasing. Two and a half hours later the cyclic fluctuations were observed again.

The next experiment was carried out to see how high temperatures of the root zone would affect on cyclic fluctuations in leaf thickness (Fig. 2). The temperature was raised at a rate of $1.5^{\circ} \mathrm{C}$ per hour from 24 to $36^{\circ} \mathrm{C}$. In this case, however, the cyclic fluctuations did not disappear even at $36^{\circ} \mathrm{C}$. The absolute leaf thickness also did not change so drastically as observed in Fig. 1. Figs. 3 and 4 show the results from similar experiments conducted in middle and late November. Physiologically it seems significant to see such an evidence that the critical temperature at which cyclic fluctuations disappeared was lower in the middle of November than in early October. Further, Fig. 3 shows that it took about 8

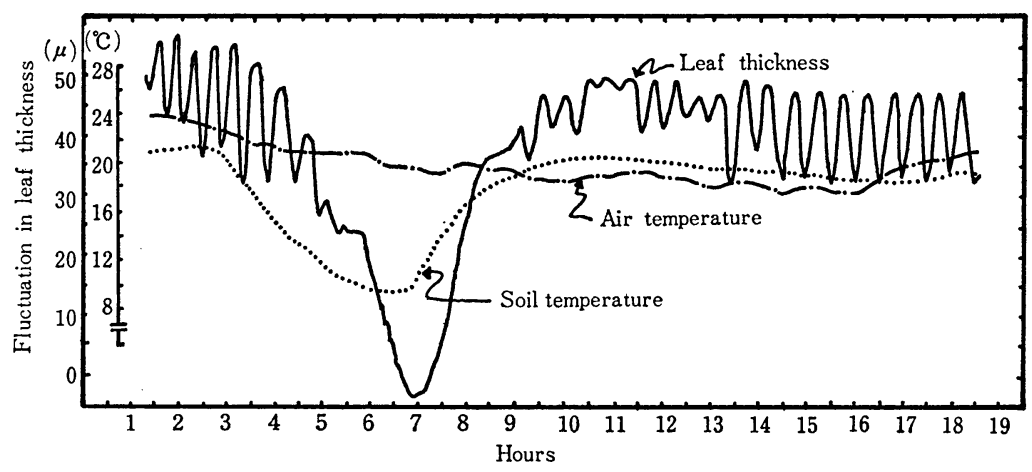

Fig. 3. Effect of low soil temperature on the cyclic fluctuations of leaf thickness in the middle of November. 


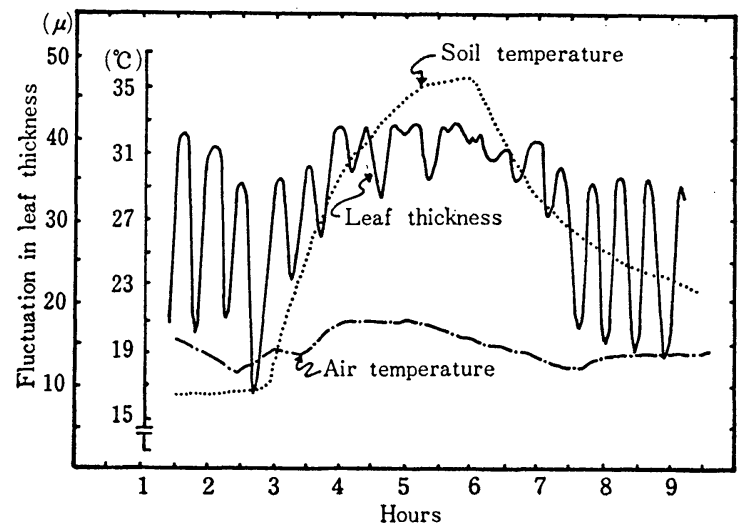

Fig. 4. Effect of high soil temperature on the cyclic fluctuations of leaf thickness in late November.

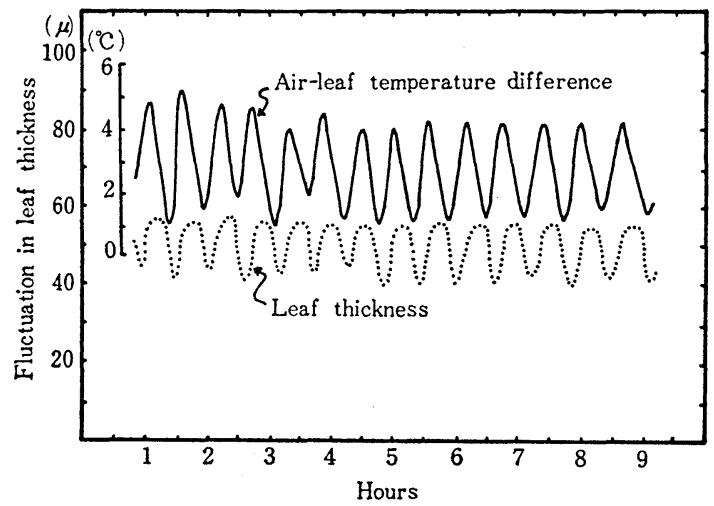

Fig. 5. Cyclic fluctuations in leaf thickness and in temperature difference between air and leaf.

hours to recover the cyclic fluctuations after raising the soil temperature, i. e., the time interval to recover cycling was longer in November than in early October. Fig. 4 shows that cyclic fluctuations became irregular above $35^{\circ} \mathrm{C}$ in late November. However, when the soil temperature was lowered, they appeared again below $30^{\circ} \mathrm{C}$.

Fig. 5 shows cyclic oscillations in leaf thickness and in leaf-air temperature differences. Harmonic analysis of the oscillations indicates that the cycle periods in the early half and in the later half were $33 \mathrm{~min}$ and $36 \mathrm{~min}$, respectively. The lag time of the oscillations in leaf thickness was $553 \mathrm{sec}$ at the beginning and later it became $641 \mathrm{sec}$. Cyclic changes in leaf temperature seem to be associated with changes in transpiration rate, a low temperature being associated with higher rates of transpiration.

\section{Discussion}

Many workers have reported on cyclic oscillations in stomatal aperture, transpiration rate and photosynthetic rate $(1,2,4,8$, 10). However, no one has yet explained the mechanism responsible for these oscillations although there is an agreement that all these cyclic phenomena result from the oscillation in stomatal aperture(8). In this experiment, transpiration proved to occur in an oscillatory manner. In addition to the previous paper (7), it was confirmed that environmental conditions of the root system would affect the cyclic fluctuations considerably. $\operatorname{Barrs}(1)$ pointed out that cycling could be initiated in a cotton plant when root temperature was $18^{\circ} \mathrm{C}$ and root resistance to absorb water was high; but cycling did not appear when root temperature was $30^{\circ} \mathrm{C}$ and root resistance was low. However, the results obtained here indicate that root response to the environmental conditions is not always the same at different seasons of the year. In early October, when the root temperature was above $17^{\circ} \mathrm{C}$, cycling was observed, whereas it disappeared above $35^{\circ} \mathrm{C}$ in late November when the lower limit of the temperature was $11^{\circ} \mathrm{C}$. Thus, from the view point of cyclic phenomena, it may be well to point out that the suitable range of root temperature was rather higher in early October than in late November. Fig. 6 shows the soil temperatures of November 28 and 29 at various depths in the field. In early morning the soil temperature near the surface was so low that roots seemed to be inactivated considerably (11).

Although there is a general belief that a restricted supply of water to leaves is a necessary factor for the occurrence of cycling (8), there is no agreement in the explanation how root resistance against water absorption (12) affects the phenomenon. Cowan(3) proposed a theoretical model in an electric analogue. Brogardh et al. (2) examined and modified the Cowan's model. In the Cowan's model he postulated that increase of water potential in gurd cells causes an increase in stomatal conductance and that increase of water potential in the subsidiary cells has the opposite effect and provides the positive feed- 


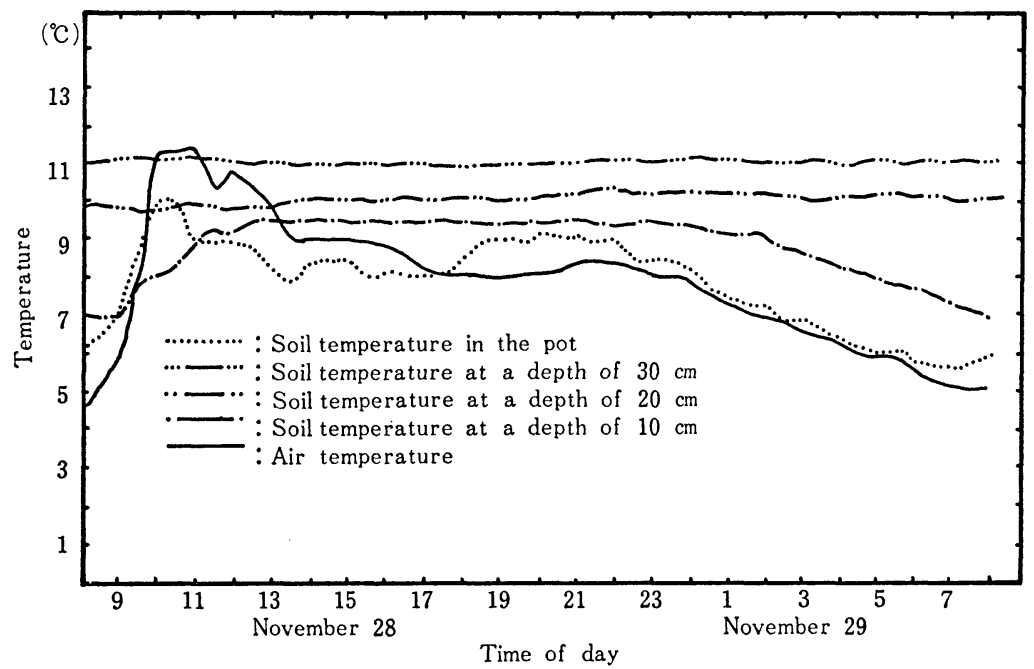

Fig. 6. Air and soil temperatures at various depths in the field. Temperatures were recorded from November 28 to 29, in 1976.

back which can cause stomatal conductance to oscillate. On the other hand, Meidner et al. (9) pointed out that the magnitude of resistance and capacitance of plant tissues may change in quite complicated ways. The results obtained here also indicate that root resistance changes not only depending on the root temperature but also with the advancement of the season. Further study is necessary to clarify the 'non-linear effects' that Cowan mentioned.

\section{Acknowledgement}

The author wishes to express his gratitude to Dr. Kazuo Matsumoto, Professor of Ehime University, for his constant encouragement. Thanks are also due to Dr. Yasushi Hashimoto, Associate Professor of Ehime University, for his useful advice in monitoring leaf temperature.

\section{Literature Cited}

1. BARRS, H. D. 1971. Cyclic variations in stomatal aperture, transpiration and leaf water potential under constant environmental conditions. Ann. Rev. Plant Physiol. 22 : 223236.

2. BROGARDH, T., T. JOHNSON, and R. KLOCKARE. 1974. Oscillatory transpiration and water uptake of Avena plants. V. Influence of the water potential of the root medium. Physiol. Plant. $32: 258-267$.

3. CowAN, I. R. 1972. Oscillations in stomatal conductance and plant functioning associated with stomatal conductance: Observations and a model. Planta $106: 185-219$.

4. Cox, E. F. 1968. Cyclic changes in transpiration of sunflower leaves in a steady environment. J. Exp. Bot. $19: 167-175$.

5. Hino, A., S. Amano, Y. Sawamura, S. SaSaki, and T. KURAOKA. 1974. Studies on photosynthetic activity in several kinds of fruit trees. J. Japan. Soc. Hort. Sci. $43:$ 209-414. (Japanese with English summary)

6. KADOYA, K., K. KAMEDA, S.CHIKAIZUMI, and K. MATSUMOTO. 1975. Studies on the hydrophysiological rhythms of citrus trees. I. Cyclic fluctuations of leaf thickness and stem diameter of Natsudaidai seedlings. J. Japan. Soc. Hort. Sci. $44: 260-264$.

7. 1977. Studies on the hydrophysiological rhythms of citrus trees. II. Seasonal effects of carbon dioxide on the cyclic fluctuations of leaf thickness. J. Japan. Soc. Hort. Sci. 46 : 153-157.

8. LANG, A.R.G., B. KLEPPER, and M. J. CuMMING. 1969. Leaf water balance during oscillation of stomatal aperture. Plant Physiol. $44: 826-830$.

9. Meidner, H., and D. W. SherifF. 1976. Water and Plants. pp. 67-82. Blackie \& Son. London.

10. RASCHKe, K. 1975. Stomatal action. Ann. Rev. Plant Physiol. $26: 309-340$.

11. Reuther, W. 1973. Climate and citrus behaviour. In : Reuther, W. (ed.). Citrus Industry III : $280-337$.

12. SKidmore, E. L., and J. F. Stone. 1964. Physiological role in regulating transpiration rate of the cotton plant. Agron. J. $56: 405-410$. 


\title{
柑樀樹の水分収支に起因する周期的微細変動現象 \\ に関する研究（第 3 報） \\ 地温がナツダイダイ実生葉厚さの変動現象に及ぼす影響
}

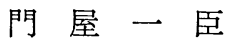 \\ (愛媛大学 農学部)
}

\begin{abstract}
摘 要
地温と葉の厚さの変動現象との関係を追跡した. 10月 上旬に拈いては, 地温の低下と共に, 葉の厚さは薄くな り, 地温が約 $17^{\circ} \mathrm{C}$ 飞低下すると周期現象が消失した. ところが，11月中旬に同様の処理をしたところ, 周期現

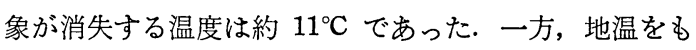
との温度にもどしたところ，10月上旬では地温の上昇に 伴って葉の厚さが厚くなり, 間もなく周期現象が回復し た. しかし，11月中下旬になると，地温の上昇に伴って， 葉は厚くなったが，再び周期現象が認められるまでには 長い時間を要した. 10月中旬には地温を $36^{\circ} \mathrm{C}$ 近くまで 上げても周期現象にそれほど顕著な変化が認められなか

ったが, 11 月下旬では, $35^{\circ} \mathrm{C}$ 近くで, 周期現象の乱れ を生ずるに至った．このとき地温を再び $30^{\circ} \mathrm{C}$ 以下に低 下させると周期現象が回復した. 以上の結果から，10月 中旬までと, 11月中旬以降とでは, 根の地温に対する適 応性が異なり, 前者ではその適温域が比較的高いところ にあるのに対して, 後者では適温域がさらに低温側に移 っているものと推察される.

次に, 葉温および葉の厚さの周期变動について調和解 析をしたところ，葉の厚さは葉温の変化に対して約 553 秒から 641 秒の遅れで同調していることが明らかとなっ た.
\end{abstract}

